\title{
Portrait of Women as Victims of Male Violence In Kompas Selected Short Stories during the Reformation Era
}

\author{
By Harris Effendi Thahar ${ }^{1}$, Nursaid ${ }^{2}$, dan Mohammad Isa Gautama ${ }^{3}$ \\ \{harrispadang@fbs.unp.ac.id ${ }^{1}$ \} \\ ${ }^{1,2,3}$ Universitas Negeri Padang, Indonesia
}

\begin{abstract}
This study aimed to reveal the form of violence against women by men in Kompas selected short stories published in reformation era, particularly related to patriarchal culture. This study applied qualitative methods and feminist literary approaches. The short stories analyzed were 'Liang' by Indra Tranggono (2004), 'Dua Wanita Cantik' by Jujur Prananto (2004), 'Ripin' by Ugoran Prasad (2005), 'Suatu hari, Ada Ibu and Radian' (2009), and 'Sonya Rury' by Indra Tranggono (2010). The research findings proved that female characters are victims of violence by men both as husbands and lovers. Forms of violence consist of direct violence and indirect violence. The violence occurs mainly caused by the presence of patriarchal issues and economic factors. The violence affects the destruction of future life as happens to Ripin whose the life was miserable, Wasti who raised four children without knowing who the father of each child wss, Radian's mother character who managed to escape along with Radian for killing Radian's father, Sonya who ended his life, and Meta who was going to experience her mother's fate, becoming a widow without getting married.
\end{abstract}

Keywords: violence, women, Kompas short stories, feminist literature.

\section{Introduction}

Violence acts reported by media to this day are still dominated by violence against women. In fact, according to Komnas Perempuan (National Women's Commission) violence against women increased by $14 \%$ in 2018 compared to the previous year ${ }^{[1]}$. There were 348,446 cases of violence against women during 2018, both those reported and those handled by Komnas Perempuan. Violence against women is also dominated by sexual violence.

Mass media are never lacking news about violence. The violence allegedly becomes part of a daily event, particularly in big cities that are indeed vulnerable to social conflicts. Perpetrators of violence are possibly anyone without distinguishing social, ethnic, or religious status. On the contrary, the acts of violence that occurred during the New Order government were generally carried out by the government and its allies, specifically the military. This was revealed from the results of the author's dissertation (Thahar, 2007 at.all) through the research on Kompas selected short stories during the New Order government which reflects this violence $^{[2]}$.

A Short story is one of the literary genres that have been written in the country and published on newspaper since the 1980s. As a literary work, short stories are expressions of authors written in the form of stories and inevitably a reflection of the author's own life as well. From the perspective of the Sociology of Literature (Ratna, 2004), literary works (novels, short stories, poetry, and drama) are representations of social situations at certain times and places. 
The Kompas daily newspaper is one of newspapers that consistently publish weekly short stories. Since 1992, the published short stories over the year are reselected to be published as an annual book of selected short stories. Therefore, it can be assumed that all the best writers over the country must submit their works to be published in this newspaper. Eventually, the Kompas newspaper contributes to the appearance of new writers.

Since the beginning of the Reformation Era, numbers of short stories on the Kompas have taken violence as a theme, as a reflection of the social situation of the author's life as well. In specific, the violence told in the short stories was violence against women, where women become victims of violence. The selected short stories which tell about violence against women are: (1) "Liang" by Indra Tranggono published in 'Sepi pun Menari di Tepi Hari' (2004), (2) "Dua Wanita Cantik" by Honest Prananto, published in 'Sepi pun Menari di Tepi Hari (2004), (3) "Ripin" by Ugoran Prasad published in Ripi's group (2005-2006), "Pada Suatu Hari, Ada Ibu dan Radian" by Avianti Armand, published in a collection with similar title (2009), and (5) "Sonya Rury" by Indra Tranggono, published in "Dodolit Dodolit Dodolibret" (2010) [3], [4], [5], [6], [7].

These five short stories were selected based on the occurrence of violence against women which affects women becoming victims, both directly and indirectly. Besides, the five short stories can represent the themes of violence among the selected short stories on the Kompas during the post Reformation period (2000-2010).

This study aims to: (1) uncover the forms of violence experienced by female characters which are done by men in five Kompas selected short stories conveying violence theme during post-reformation era; (2) revealing the background of the violence occurrence done by male characters and experienced by female characters in those five short stories; and (3) expose the impact of violence done by men to female characters as reflected in the short stories of (a) Liang by Indra Tranggono, (b) Dua Wanita Cantik by Jujur Prananto, (c) Ripin by Ugoran Prasad, (d) Pada Suatu Hari Ada Ibu and Radian by Avianti Armand, and (e) Sonya Rury by Indra Tranggono.

Rokhmansyah et al. ${ }^{[8]}$ stated that violence against women generally occurs due to the patriarchal culture that is still rooted in society ${ }^{[10]}$. In a patriarchal culture, male power is absolute power and cannot be changed. Men occupy positions as leaders and rulers, while women as workers and servants for men.

Galtung $^{[9]}$ divided violence into two, namely: (1) direct violence, physical violence which seen as behavior, such as injuring, killing and war; and (2) invisible violence or structural violence. In addition, Gender Equality Index-Report ${ }^{[11]}$ distinguished violence against women into two categories: direct violence and indirect violence.

Direct violence against women focuses on all gender-based actions that result in physical, sexual or psychological harm to women including the threat of coercion or arbitrary deprivation, both publicly and privately. Meanwhile, indirect violence in gender context focuses mainly on attitudes, strategies and cultural norms supporting gender practices that can lead to gender violence ${ }^{[9]}$.

\section{Method}

This research is a qualitative study applying feminist literary critique. Source of data in this study are short stories included in Kompas selected short stories book in the year of 2004, 2005/2006, 2009, and 2010 in which one short story represents each year : (1) Liang by Indra Tranggono, (2) Dua Wanita Cantik by Honest Prananto, (3 ) Ripin by Ugoran Prasad, (4) 
Pada Suatu Hari, Ada Ibu dan Radian by Avianti Armand, and (5) Sonya Rury by Indra Tranggono [3], [4], [5], [6], [7].

This study was conducted by following five steps of the research process. First, the researcher did a heuristic reading of short stories and continued by reading hermeneutically to get a more detailed understanding. Second, the researcher recorded all data needed in accordance with the indicators of each research question. Third, tabulation and classification of data are made regarding the indicators determined. Fourth, the researcher analyzed the data by confirming to the formulation of the problem to achieve the objectives of the study. Fifth, a descriptive analysis of the data was performed. Last, the researcher wrote the conclusion of this study.

\section{Findings and Discussion}

In general, the five short stories analyzed in this research represent violence committed by men against women. Some male perpetrators of violence have relations as a husband to the victims and some do not. This is somehow related to the form of direct and indirect violence in which the female characters in the short stories become victims both physically and nonphysically (psychologically).

Figure 1. Women as Victims of Male Violance

\begin{tabular}{|c|c|c|c|c|c|c|}
\hline \multirow{3}{*}{ No } & \multirow{3}{*}{ Title of Short Story } & \multicolumn{5}{|c|}{ Male Violence Against Women } \\
\hline & & \multirow{2}{*}{$\begin{array}{l}\text { Background of } \\
\text { the Violence }\end{array}$} & \multicolumn{2}{|c|}{ Direct Violence } & \multirow{2}{*}{$\begin{array}{l}\text { Indirect } \\
\text { Violence }\end{array}$} & \multirow[t]{2}{*}{ Consequence } \\
\hline & & & Physical & $\begin{array}{c}\text { Non- } \\
\text { physical }\end{array}$ & & \\
\hline 1. & Liang & Economy & $\mathrm{v}$ & & & $\begin{array}{l}\text { Being unable to } \\
\text { control her emotion } \\
\text { about the neighbours' } \\
\text { sarcasm and killed one } \\
\text { of them }\end{array}$ \\
\hline 2. & Dua Wanita Cantik & Economy & $\mathrm{V}$ & $\mathrm{v}$ & $\mathrm{v}$ & $\begin{array}{l}\text { Being psychologically } \\
\text { suffered because of } \\
\text { having children } \\
\text { without getting } \\
\text { married }\end{array}$ \\
\hline 3. & Ripin & Patriarchy & $\mathrm{v}$ & & & $\begin{array}{l}\text { The death of Mak } \\
\text { character because of } \\
\text { her head being blasted } \\
\text { away to the wall by } \\
\text { Bapak }\end{array}$ \\
\hline 4. & $\begin{array}{l}\text { Pada Suatu Hari, Ada } \\
\text { Ibu dan Radian }\end{array}$ & Patriarchy & $\mathrm{V}$ & & & $\begin{array}{l}\text { The death of Bapak } \\
\text { character because of } \\
\text { being stabbed by } \\
\text { Radian }\end{array}$ \\
\hline 5. & Sonya Rury & $\begin{array}{l}\text { Economy/Biologi } \\
\text { cal need }\end{array}$ & $\mathrm{v}$ & $\mathrm{v}$ & $\mathrm{v}$ & The death of Sonya \\
\hline
\end{tabular}




\subsection{Description of Woman Figure}

\section{Liang Short Story by Indra Tranggono}

Wasti was the only daughter of Yu Milah. Yu Milah used to be a prima donna among Ketoprak seller and was impregnated by a man. Unfortunately, the man disappeared after knowing about Yu Milah's pregnancy. Yu Milah lived in a $3 \times 3 \mathrm{M}^{2}$ house in a high-density village. Yu Milah did not want Wasti to have the same fate as her, living a life as a fatherless kid. Therefore, she was sent to school. After Wasti graduated from high school, economic problems made her unable to go to college.

Finally, after graduating from school Wasti went to town and got a job. However, Yu Milah did not know where her daughter worked. The only thing she knew was Wasti sent her a lot of money. With that money, Yu Milah could repair her house and facilitate it with furniture. It turned out that Wasti was working in a club and becoming a courtesan for wealthy men.

A man who had slept with her gave her a cheque worth millions and left a message "Good morning, dear," on her cellphone screen. Wasti wanted to make the man her husband, but the man disappeared after she sent him a reply "Why so hurry, dear?".

Wasti had slept with different men she did not know. As a result, every year she returned to the village taking her babies with her without knowing who the father of the babies is.

Satirical responses of neighbors are inevitable.

"Well, if every year Wasti comes home with a child, our village must be crowded" a fat woman laughed. The laughter was greeted by customers who clustered around moneylenders.

"It's not like that, huh. Uh, probably she wanted to imply that you are infertile" said the thin woman with laughter.

"Eventhough I am infertile, I have my husband ..." [7]

The insinuation that hurt Wasti and Yu Milah triggered Yu Milah to pull out an iron bar at the door of her house and beat the fat lady and caused her to pass out. Yu Milah was then arrested by the police.

\section{2. 'Dua Wanita Cantik' Short Story by Jujur Prananto}

A beautiful mother figure, Yustin, was so worried to see her daughter's beauty, Meta, who had been caught storing lipstick in her bag. Her concern was Meta's fate. She was afraid if her daughter's fate later was a repetition of his fate. When she was at Meta's age, her beauty made all the men tempted and the one who succeeded in seizing his virginity was Meta's biological father who disappeared from her life.

"There is only one condition you must obey: Do not disturb my wife and children." And Yustin has no power to sue. Years later, the man disappeared without any notification. Suddenly, Yustin's debit card was rejected by the cashier and a group of people came to her house and claimed it as their house. From that day she suddenly realized that the baby she was pregnant with would never have a father ${ }^{[4]}$.

That does not seem unreasonable because one day Meta was caught answering a phone call in secret.

"Wait a minute ...!" But the telephone on the other side had been hung off. And what was heard later was the voice of her mother standing right in front of the door outside the room and asked: "Who are you talking to, Meta?" [4] 


\section{3. 'Ripin' Short story by Ugoran Prasad}

Ripin was a child who lived in a village and liked to play marbles. One day, there was a sound from a pick-up car singing Rhoma Irama songs. The car was decorated by colorful posters announcing there would be a night market, a 'Demon Barrel' game, and fascinating Rhoma Irama's performance. Ripin asked his mother to invite him to the event. His mother is blowing her traditional stove in the kitchen. Mak just said 'There was no night market. There was no demon barrel game'.

Ripin knew that Mak was quietly crying every time she heard Rhoma Irama singing on the radio. Ripin even saw Mak holding and cradling the radio even though Mak had sworn she would not cry no matter how hard Ripin's father hit her face ${ }^{[5]}$.

Ripin's father is a bandit who slept all day and went out all night and returned before dawn. Lately, he did not go out late at night because many of the bandits were shot dead mysteriously. Even though he still beat Mak, he taught Ripin to get ready to be beaten by rattan. A bitter fact that was not understood by Ripin decades later, his Mak died after her head was knocked down against the wall by his father. His father's body was found floating at times with a wound on his chest and forehead shot by another spooky gangster called Petrus.

\section{1 'Pada Suatu Hari, Ada Ibu dan Radian' Short Story by Avianti Armand}

This short story tells about a mother and her son who is still a boy named Radian who liked to draw as an impingement for his emotions. At school, Radian strangled a hamster to death in front of his friends and teachers. However, he was shaken. Radian was shocked to see his mother strangled by his father yesterday morning. His mother was not dead, but she was knocked down on the floor.

My neck was chattering. My head almost broke. When the consciousness was almost gone, he suddenly dumped me - lying on the floor, reaching up to the unwilling air to breathe. He just left. And when my eyes recovered, my heart sank. Radian stared from a dark silent corner ${ }^{[6]}$.

In the morning, the mother got Radian's room empty, but still warm. He found Radian startled in front of the bathroom. There, his father was laid down with a knife still stuck in his bloodied chest.

\section{2 ‘Sonya Ruri’ by Indra Tranggono}

A woman who worked as a cafe waiter, named Sonya Rury, declared that she had just divorced her husband. She confessed to the $M e$ (the narrator) that she and her ex-husband were just lived together. During that time she was sold by her ex-husband to numerous strangers. Her ex-husband threated her that he would injure and kill her. The woman's back was full of wounds caused by a folding knife incision done by her ex-husband.

In her teenage, Sonya had been raped by a middle-aged man. Not only that, she was also sexually harassed by the boss of a company. Furthermore, she always became a victim of sexual abuse before he met her ex-husband, a charming-faced man. He said that he was in love with her and they both lived together.

\subsection{Discussion}

The form of direct violence experienced by Mak Ripin character (in Ripin), Mrs. Radian (in 
Pada Suatu Hari, Ada Ibu dan Radian), and Sonya (in Sonya Rury) belongs to physical violence. As revealed by Galtung (2003), physical violence is a form of classical violence such as: throwing objects at the victim's body, beatings, slaps, strangling, kicking, stomping, injuring victims with weapons or empty-handed.

The three short stories above clearly describe about the suffering of women as victims of violence done by men who are in official and unregistered marital status with the victims. For example, Ripin's father, a bandit, wandering all night and sleeping during the day, often beats Mak (Ripin's mother). One day, Ripin's father caught Mak watching the outdoor cinema screening. She was immediately beaten by Ripin's father until the morning. In this story, Mak died after his head was knocked against the wall. Ripin's Father also died because of being shot by a mysterious shooter.

The reason for the violence done by Bapak character against Mak Ripin is all about the patriarchal culture embraced ${ }^{[13],[14]}$ by the Javanese rural community as the background of the story. Furthermore, this short story took place in the New Order era of Indonesia when bandits or gangsters were finally banished by mysterious shootings, without going through the court (extrajudicial killing).

In the following quote:

"The woman showed the picture to her husband at dinner time. The principal had shown her the picture this morning. Radian's drawing. The man did not say a word. He just hit the table, grabbed the plate, and threw it away. Right to her face. She choked out. The pain almost blew up her head. She swallowed it. Anger ambushed immediately. She swallowed it. The deafening noise of smashing plates ${ }^{[6]}$.

Radian's mother was told that she had not dissolved her husband's physical abuse. The marriage of Radian's parents was not based on love. Therefore, they had to get married because Radian's mother was already pregnant. The violence which was always witnessed by Radian triggered him to kill his father in the bathroom by stabbing a knife in the chest. Similar to Ripin's father case, Radian's father also adheres to a patriarchal culture that considers women to be under the power of men. The impact of the violence was the destruction of the marriage and the death of the father by the hands of his son.

Another case experienced by Sonya character (in Sonya Rury). She is a victim of genderbased direct violence that results in physical, sexual, or psychological harm to women, including threats of action and intimidation. The violence is also motivated by cultural violence, namely violence based on male supremacy (gender-based). The impact of the violence on Sonya's character is her death.

Direct and indirect violence experienced by Wasti character (in Liang) is fundamentally based on economic problems. Wasti who was born without knowing who her father was, chose to get a job in the city even though her mother, Yu Milah, wanted her to go to college. Poverty in her life forces Wasti to accept any work that earns a lot of money. Wasti earns a lot of money from men she has slept with. She then gives the money to her mother to repair their house and provide sufficient furniture. The risk of her work is that she has to take along with her new babies every year she returns home from the result of her relationship with several men who gave her money but do not legally marry her.

Wasti is a victim of gender-based direct violence done by men who give her a lot of money. The form of indirect violence experienced by Wasti is psychological violence. It psychologically affects her for being a pregnant woman and a mother to three children without marriage. This psychological violence has a significant effect on her and her mother's life. Satirical statements coming out from the community push them down. This stress results in 
Wasti's mother desperately striking her sarcastic neighbor with an iron peg. Nonetheless, there has been a spiral of violence as cited by Camara [17], [18], [19].

Yustin, a female character in Dua Perempuan Cantik, also psychologically experiences gender based violence both directly and indirectly. Yustin experiences this gender-based violence because her beauty makes her the target of men's aggressive behavior. She is pregnant and gives birth to a beautiful daughter named Meta. Instead of being responsible, the man who makes her a mistress disappears, along with his financial support which he used to give. Her experience concerns her to worry about Meta who is growing to be a beautiful woman. She is afraid that Meta will become a victim of gender based violence like she did in the past. Her fear comes true.

The violence experienced by Yustin and Meta was based on a patriarchal culture which has an impact on Meta's future. It results in the obscurity in Meta's future to have a normal and harmony family.

\section{Conclusion}

The theme of those five short stories analyzed in this research is women as victims of male violence published by the Kompas newspaper. The Kompas newspaper was published in the era of reformation (the era when the press was no longer controlled by the government). The short stories represent the social situation at the time they were written. In general, the five short stories studied include a portrait of violence done by men against women.

Three short stories are illustrations of direct physical violence (Ripin, Pada Suatu Hari, Ada Ibu and Radian, and Sonya Rury) which derive from patriarchal culture or the supremacy of male power covered by different social issues such as economic and education.

Other two short stories: Liang and Dua Wanita Cantik portray the gender-based violence that causes Wasti and Yustin characters experience violence directly and indirectly. In the beginning, Wasti and Yustin get the violence is by compulsion or under a threat. However, it turns out later that they are finally used to it and take it as a dirty work to earn a lot of money easily. As a result, both of them are victimized and become women who give birth to children without legally getting married and the fathers of their children remain unknown.

The recent violent incidents reported by the media are still interesting themes for several authors. Based on the findings of this research, women will always be the victims of male violence if the patriarchal culture still dominates this world. This is different from Bonilla's findings ${ }^{[20]}$, that violence occurs due to the culture of class differences, where the lower class are willing to be oppressed, become victims of violence ${ }^{[20]}$.

\section{Acknowledgement}

The research and writing of this article was funded by LP2M of Universitas Negeri Padang Fiscal year 2019 contract No: 821 / UN35.13 / LT / 2019.

\section{REFERENCES}

[1] Tempo.2018. "Perubahan RUU Penghapusan Kekerasan Seksual Mandek" https:// Koran.tempo.co/27.11.18. diakses 10 Juni 2019.

[2] Thahar, H. E. 2006. "Kekerasan dalam Cerpen-cerpen Pilihan Kompas 1992-1990. Suatu Tinjauan Struktural Genetik" dalam Jurnal Pendidikan dan Kebudayaan, Vol.12/062-ISSN 0215-2673 
[3] Tranggono, I. 2010. "Sonya Rury" dalam dodolit dodolit dodolibret, Cerpen Pilihan Kompas 2010. Jakarta: Penerbit Buku Kompas.

[4] Prananto. J. 2004. "Dua Wanita Cantik" dalam Sepi pun Menari di Tepi Hari. Jakarta: Penerbit Buku Kompas.

[5] Prasad, U. 2005. "Ripin" dalam Ripin, Cerpen Pilihan Kompas 2005/2006. Jakarta: Penerbit Buku Kompas.

[6] Armand, A. 2009. "Pada Suatu Hari, Ada Ibu dan Radian" dalam Pada Suatu Hari, Ada Ibu dan Radian. Jakarta: Penerbit Buku Kompas.

[7] Tranggono, I. 2004. "Liang” dalam Sepi pun Menari di Tepi Hari, Kumpulan Cerpen Pilihan Kompas 2004. Jakarta: Penerbit Buku Kompas.

[8] Rokhmadsyah, A.,Valiantien, N. M.,dan Giriani, N. P.2018. "Kekerasan terhadap Perempuan dalam Cerpen-cerpen Karya Oka Rosmini” dalam Jurnal Litera, 17/n0.3 November 2018

[9] Galtung, J. 2003. Studi Perdamaian:Perdamaian dan Konflik Pembangunan dan Peradaban. Surabaya: Pustaka Eureka.

[10] Rosida,I \& Rejeki,L.2007."Women in Patriarchal Culture: Gender Discrimination and Intertectionality Portrayet in "Bob Darling" by Carolyn Cooke, Insaniyat, Journal of Islam and Humanities, Vol.1(2).Mei 2017, diakses 10 Juni 2019.

[11] Gender Equallity Index-Report. 2013. Vilnius. Retrieved from http://eige.euroa.eu/sites/defaul/files/document/ Gender-Equality-Index-Report.pdf

[12] Ratna, N. K. 2004. Penelitian Sastra: Yogyakarta: Pustaka Pelajar.

[13] Subhan, Z. 2004. Kekerasan terhadap Perempuan. Yogyakarta: Pustaka Pesantren.

[14] Sulhin, I. 2016. "Kekerasan dan Kultur Patriarki" Retrieved from https://nasiolan.kompas.com/read/2016/05/05/09402831/Kekerasan.dan.Kultur.Patriark i

[15] Meilina, S. 2016. "Fenomena Kekerasan Gender dalam Nonel-novel Karya Danielle Steel".dalam Litera, Jurnal Bahasa, Sastra, dan Pengajarannya, 15 (1), 147-159. https://doi.org/10.21831/ltr.v15i1.9775 diakses 10 Juni 2019.

[16] Putra, I.N.D. 2003. "Cerpen yang Menghindari Konflik", dalam Waktu Nayla Cerpen Pilihan Kompas 2003, Jakarta: Penerbit Buku Kompas.

[17] Fitriani, D.\& Wildan.2017. "Kekeran terhadap Perempuan dalam Novel Bidadari Hitam Karya TI.Thamrin” dalam Master Bahasa 5(2), 78-87. Retrieved from http://jurnal.unsyiah.ac.id/MB/article/view/11080/8838 diakses 11 Juni 2019.

[18] Camara, D. H. 2005. Spiral Kekerasan, Terjemahan Komunitas Apiru. Magelang: Resist Book.

[19] Eriyanti,L.D.2017.'Pemikiran Johan Galtung tentang Kekerasan dalam Perspektif Feminisme" dalam Jurnal Hubungan Internasional, 6 (1), 17-27. https://doi.org/10.18196/hi.61102

[20] Bonilla,C. 2016. Reason for Violence: A Study of RK. Narayan's “Another Community”. Indi@logs Vol.3.2016.pp.19-25. ISSN 2339-DOI http://dx.doi.org/10.5565/eev/indialogs.40 diakses 5 Juni 2019. 